KWANG-KYUN LIM, Ph.D.

E-mail: ikay@songwon.ac.kr

Songwon University

Department of Railroad Management

Nam-gu Song-ahm ro 73, Gwangju, Korea
Transport Technology Original Scientific Paper Submitted: 16 Oct. 2019

Accepted: 2 Aug. 2020

\title{
ESTIMATING A NEW FARE FOR SIGHTSEEING TRAINS BASED ON WILLINGNESS TO PAY
}

\begin{abstract}
Since high-speed train operation in 2004 in Korea, the revenue of conventional trains has been rapidly declining. To overcome the circumstance even a little, sightseeing trains have been introduced along ten competitive routes since 2013, which helped to reduce the loss rate from 3.0 to 2.5 compared to the existing conventional trains. Such accomplishment was based on the existing fare system fitted to conventional trains, not reflecting the value of the unique service that only the sightseeing train provides. The understanding of the Willingness To Pay (WTP) has largely remained unexplored in the railway transportation literature, and further no contributions in the sightseeing train industry. The paper aims to estimate the economic value of various types of service for sightseeing trains in the contexture of the WTP postulates using open-ended question survey data and a Tobit censored regression with four different statistical structures. The normal distribution model replicates the WTPs best fitted over entire service types, and the WTPS vary by different type of train services such as recreational activities, slow-moving operation, seating type, tourist commentary and locally connected tour service. The highest value 13.3 24.2\% in room typed seats compared to observable seats has been observed. Applying the demand elasticities to price, the revenue maximizing is observed at a $6 \%$ hike for a standard seat and a $22 \%$ hike for a designated seat, and the revenue rises by $0.33 \%$ to $3.54 \%$. This study expects that the result can be used as an appropriate guideline in determining a new fare fitted to sightseeing trains.
\end{abstract}

\section{KEY WORDS}

willingness to pay; sightseeing train; demand elasticity; Tobit censored regression model;

\section{INTRODUCTION}

The Korea Railroad Corporation (Korail), which operates the national rail network, is a public corporation that pursues both public interests and their own profits. Korail operates three types of railways: an urban train linking Seoul and the surrounding satellite cities, two nationwide trains (conventional trains and high-speed trains running over 300 $\mathrm{km} / \mathrm{h}$ ). In 2017, the annual transports recorded 59.8 million passengers for high-speed trains, 74.3 million for conventional trains, and 808 million for urban trains [1].

In the case of urban and high-speed trains, the earnings reach a certain level of expenditure. However, the earning remains one third of expenditure for the conventional trains.

In detail, the high-speed trains had recorded operating profit of 441 billion won $(1,120$ won $=1$ USD in Aug 2017), while the conventional trains recorded 594 billion won lost in 2017. The urban trains had a loss of 142.7 billion won in 2017, which is compared to a profit of 53 billion won in 2016 . The profits of the urban train are expected to decrease gradually due to the increase of various alternative urban railway constructions to be operated by other train operators in Seoul and the surrounding satellite cities. The biggest reason for the poor profit of conventional trains is due to high-speed trains. In particular, the loss is higher when the conventional train route is adjacent to the high-speed train route. For this reason, the Korean government subsidized Korail for 296.2 billion won in 2017 as a part of public service.

However, since such government subsidies alone are not enough for Korail, they have to consider various strategies that could increase profits from train operation. They had launched a new project converting some of the conventional trains that run along the scenic routes and connect tourist attractions into sightseeing trains. The sightseeing trains have been operating since 2013 by renovating the internal facilities of existing cabins to be more 
comfortable and attractive for passengers. There are six types of sightseeing trains named $\mathrm{O}, \mathrm{V}, \mathrm{S}, \mathrm{G}, \mathrm{A}$, and D-trains describing local characteristics of the operating routes.

The annual numbers of passengers carried by six sightseeing trains were 692,772 in 2016 and had a substantial drop of $-28 \%(501,307)$ in 2017 [1], when comparing the decrease rates of transport in the high-speed (-7.4\%) and conventional trains (-4.2\%) during the same period. The biggest decreases were recorded in D-train $(-55 \%, 81,663 \rightarrow 39,212)$ and A-train $(-45 \%, 85,093 \rightarrow 46,951)$. In contrast, the transport of passengers increased by $4 \%$ in G-train $(120,022 \rightarrow 124,360)$. Although the transport by sightseeing trains represents just $0.7 \%$ of the total passenger transport for all conventional train routes operated by Korail, their profit-to-cost ratio is much more attractive than the one of the conventional trains. The rates between expenditures and incomes are 2.5 (expenditure 31,875 million won and income 12,789 million won) for the sightseeing trains and 3.0 for the conventional trains in 2017.

Unlike the conventional passenger trains, which aim to carry passengers quickly and safely to their destination, a sightseeing train is intended not as practical transportation but as a leisure-style attraction to see, a tour as an activity to do, or a means to enjoy for novelty or entertainment purposes. People on the trains are more likely to be 'travellers' than to be simply 'passengers' in terms of transport purposes. In determining fare rates of sightseeing trains, however, such differences in the purpose of boarding are not considered. In other words, the conventional passenger trains emphasize more public interest rather than the operators' profitability that sightseeing trains pursue. Although the boarding purposes of sightseeing trains are different from those of the conventional passenger trains, the fare for sightseeing trains is the same as the priority seat of conventional trains (the fare of a priority seat is $15 \%$ higher than a standard seat).

Sightseeing trains offer a variety of services and activities by train crews, including performances, magic shows, recreation and more. However, the economic values of such services and activities are not reflected in the current fares at all. The fares that do not reflect such inherent characteristics of sightseeing trains, which are the purpose of the 'ride' itself, can only stay at the fare level of the public interest, like the conventional passenger trains.

Therefore, this study aims to estimate the economic values of unique services for sightseeing trains. To propose a new fare fitted to sightseeing trains, a survey will be conducted on how much passengers would be willing to pay more based on their current fare. The increase rates that passengers are willing to pay more for such unique services will be proposed to help the train operator decide on an appropriate baseline of fare hike.

\section{SIGHTSEEING TRAINS IN KOREA}

There are two kinds of sightseeing trains in Korea. One usually completes the trip within one day and another continues for more than two days. The "one-day" train runs regularly by Korail, but the "lodging" train runs irregularly by other tourism companies. This study has focused on the "one-day" trains operated by Korail.

Table 1 shows the "one-day" trains running along ten competitive routes dividing the country into five major regions as indicated in Figure 1. They are grouped into six types of sightseeing trains and

Table 1 - Sightseeing trains operated by Korail in Korea

\begin{tabular}{|c|c|c|c|c|c|c|}
\hline \multicolumn{2}{|r|}{ Routes } & \multirow{2}{*}{$\begin{array}{c}\text { Opened } \\
\text { April } 2013\end{array}$} & \multirow{2}{*}{$\begin{array}{c}1 \text { way dist. } \\
{[\mathrm{km}]}\end{array}$} & \multirow{2}{*}{$\begin{array}{c}\begin{array}{c}\text { Ops. days } \\
\text { (/week) }\end{array} \\
6\end{array}$} & \multirow{2}{*}{$\begin{array}{c}\begin{array}{c}\text { Freq. } \\
\text { (/day) }\end{array} \\
2\end{array}$} & \multirow{2}{*}{$\begin{array}{c}\begin{array}{c}\text { Seats } \\
(/ \text { train })\end{array} \\
205\end{array}$} \\
\hline O-train & Seoul Jaecheon & & & & & \\
\hline \multirow{2}{*}{ V-train } & Youngju Cheoram & \multirow{2}{*}{ April 2013} & 87 & 7 & 2 & 158 \\
\hline & Bucheon Cheoram & & 28 & 7 & 4 & 158 \\
\hline \multirow{2}{*}{ S-train } & Seoul YeosuExpo & \multirow{2}{*}{ September 2013} & 430 & 6 & 2 & 218 \\
\hline & Busan Bosung & & 269 & 6 & 2 & 218 \\
\hline \multirow{2}{*}{ D-train } & Seoul Dorasan & May 2014 & 56 & 6 & 4 & 136 \\
\hline & Seoul Baekmagoji & August 2014 & 98 & 6 & 2 & 136 \\
\hline \multirow{2}{*}{ A-train } & Chungyangri Auraji & \multirow{2}{*}{ January 2015} & 253 & 5 & 2 & 200 \\
\hline & Mindoongsan Auraji & & 39 & 5 & 2 & 200 \\
\hline G-train & Yongsan Iksan & February 2015 & 246 & 5 & 2 & 236 \\
\hline
\end{tabular}




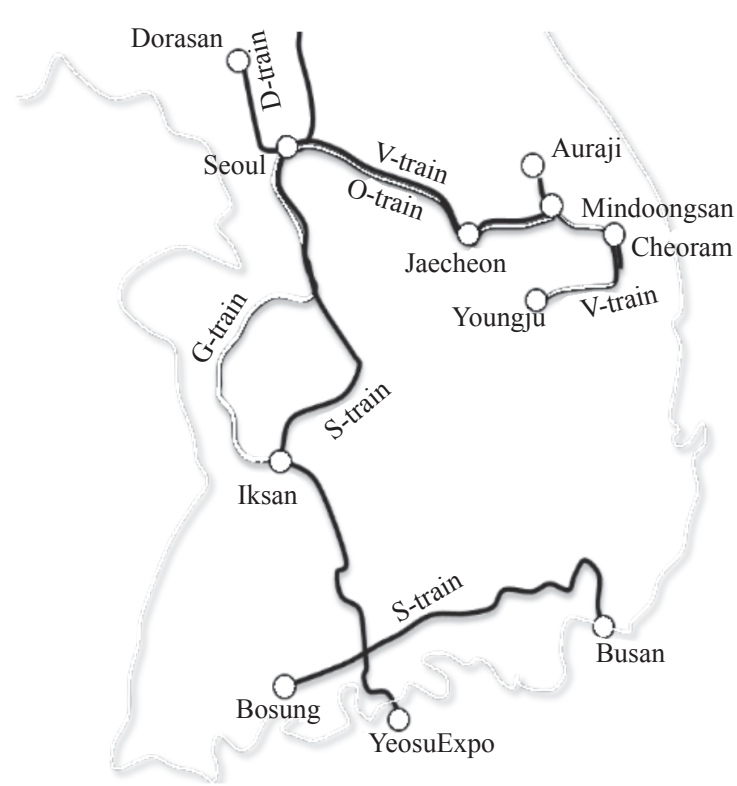

Figure 1 - A route map of sightseeing trains in Korea

operated by Korail since 2013. O-train and V-train were first opened in April 2013 and recently G-train in February 2015 [2]. The V-train (Buncheon-Cheoram route) is the shortest on $28 \mathrm{~km}$, and the S-train (Seoul-Yeosu Expo section) is the longest on 430 $\mathrm{km}$. The D-train (or called "Peace Train") departs from Seoul and visits demilitarized zone (DMZ), established in 1953 during the Korean War. All passengers are required to provide a legitimate form of identification at the intermediate stop because Dorasan is the only train station located within the civilian-restricted area. Also, passengers are additionally reminded that taking photos is highly restricted in many off-train tour sites. Since D-train operates in these unique areas, the visitors can only tour certain points after identification. Due to such characteristics, D-train has many passengers for the purpose of seeing the military confrontation between the two Koreas and feeling the pain of the division of the
Korean Peninsula, contrasting with the other trains with "entertainment" itself in the travelling purpose. In this regard, D-train's intention to raise fares is expected to be relatively higher than the others.

Charged for the fare is 110.81 won $/ \mathrm{seat} \cdot \mathrm{km}$ : $96.36 \mathrm{won} / \mathrm{seat} \cdot \mathrm{km}$ as payment for transport itself (defined as "transport payment") and additional $15 \%(14.44 \mathrm{won} / \mathrm{seat} \cdot \mathrm{km})$ for additional services not directly related to transport (defined as "service payment") [2].

First, we analysed the operating costs of all sightseeing trains operated by Korail. The cost data consist of 168 items, such as labour, general expenses, asset-related expenses and others. Those costs were reclassified into two categories: one is "Fixed costs" that are regularly spent regardless of the amounts of train operation, and "Variable costs" that vary proportionately with the amounts of train operation.

Fixed costs typically include labour costs, depreciation costs, rent, benefits, taxes and utilities. On the other hand, variable costs include product logistics costs, consumables costs, outsourcing costs, and facility usage fees that change as production activities increase. The variable cost of sightseeing trains is often higher than that of conventional trains since sightseeing trains are operated by remodelling the interior of the existing fleets of conventional trains to suit the purpose of tourism. Thus, the amount of difference in variable costs between sightseeing trains and conventional trains is defined as "additional costs" and is expected to be reflected in the fare for sightseeing trains. However, such costs were not considered as an additional income for the sightseeing train.

In the proportion of costs for overall sightseeing trains, there are $64.5 \%$ for fixed costs, $32.0 \%$ for variable costs, and $3.5 \%$ for additional costs in 2015. Figure 2 presents revenues and total cost details

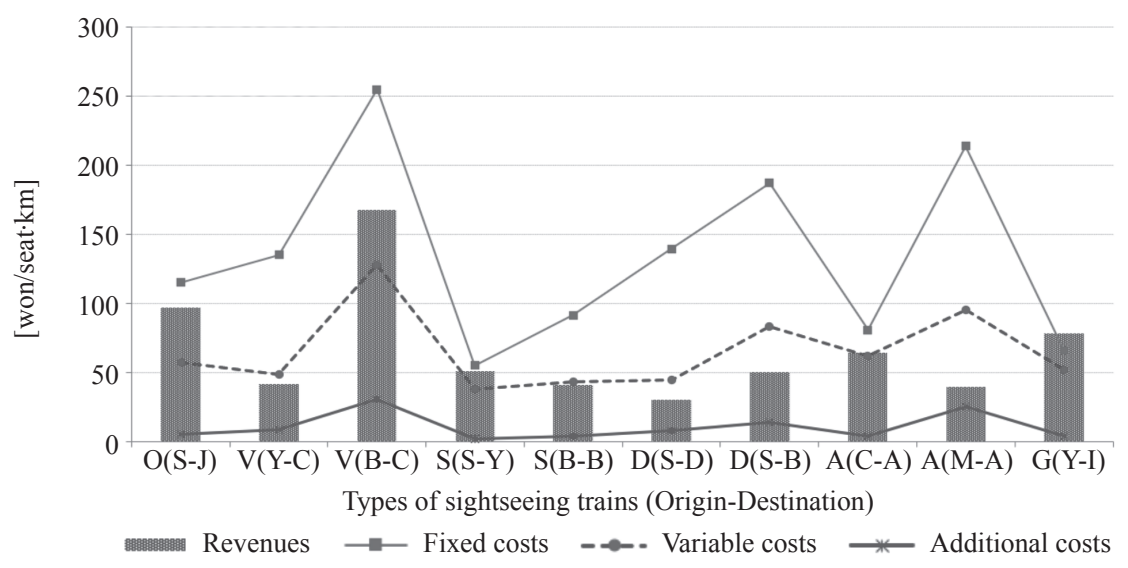

Figure 2 - Revenue vs. expenditure by sightseeing trains 
(i.e. fixed, variable, and additional costs) by each sightseeing train. The average transport expenditure for the entire sightseeing trains is 210.47 won $/ \mathrm{seat} \cdot \mathrm{km}, 3.2$ times higher than the revenue $(65.77 \mathrm{won} / \mathrm{seat} \cdot \mathrm{km})$.

On A-train (M-A: Mindoongsan-Auraji route), the income remains at one-eighth of the expenses, with the lowest performance among entire sightseeing trains. S-train (S-Y: Seoul-YeosuExpo route) is the best performer, but its income remains only onehalf of the expenses. In order to be at least equal to incomes and expenses (assuming all seats are occupied), the current unit fare (110.81 won $/ \mathrm{seat} \cdot \mathrm{km})$ has to be raised 1.9 times $(210.47$ won $/$ seat $\cdot \mathrm{km})$. However, such a high increase rate is a burden to passengers, and demand elasticity to the fare increase may reduce the profits, so a proper fare adjustment needs to maximize the operating profits of the sightseeing trains by considering such aspects.

In order to examine the appropriateness of the fare for sightseeing trains, 18 types of trains operated in five countries similar to those operated by Korail were investigated. Fourteen types of trains run less than three roundtrips per day, and 11 run daily. Tsugaru trains of Japan are operated on the same route with conventional passenger trains but had to pay an additional $¥ 400$ for boarding. The method of charging is a 'distance proportion' system, which is proportional to the distance travelled. There were limits in finding out how much more additional fees were charged compared to conventional passenger trains, as most of the routes operated by sightseeing trains were different from those operated by conventional trains.

Passengers choosing a service such as an observatory seat and a designated seat pay $17 \%$ more in Golden-Pass Line in Switzerland and $125 \%$ in Genbi Shinkansen in Japan. Table 2 shows a more detailed comparison of the fare level in various countries. According to an analysis of unit fares that reflect nominal unit prices and the Purchasing Power Parity (PPP) published by the World Bank in July 2017, they are at least 1.3 to 24.3 times higher than Korail. As the relatively low level of fare in Korea is a reason for making their profits worse, it seems necessary to raise the fares to a certain extent.

Table 2 - Sightseeing trains operating in diverse countries (as of 2017)

\begin{tabular}{|c|c|c|c|c|c|c|}
\hline \multirow{2}{*}{$\begin{array}{c}\text { Country } \\
\text { (monetary unit) }\end{array}$} & \multirow[b]{2}{*}{ Sightseeing trains } & \multirow{2}{*}{$\begin{array}{c}1 \text { way dist. } \\
{[\mathrm{km}]}\end{array}$} & \multirow{2}{*}{$\begin{array}{c}\text { Fare } \\
\text { (Own } \\
\text { monetary unit) }\end{array}$} & \multicolumn{2}{|c|}{ Fare $($ won $/$ seat $\cdot \mathrm{km})$} & \multirow{2}{*}{$\begin{array}{c}\text { Ratio } \\
\text { (PPP/110.8) }\end{array}$} \\
\hline & & & & $\begin{array}{c}\text { Monetary } \\
\text { based }\end{array}$ & PPP based & \\
\hline \multirow{8}{*}{ Japan (¥) } & Tsugaru Railway & 20.7 & 1,250 & 606.3 & 522.7 & 4.7 \\
\hline & Mojiko Retro & 2.1 & 300 & $1,434.3$ & $1,236.5$ & 11.2 \\
\hline & Resort Sirakami & 147.2 & 2,425 & 165.4 & 142.6 & 1.3 \\
\hline & Oykot & 75.3 & 2,260 & 301.3 & 259.8 & 2.3 \\
\hline & Okuizumi Orochi & 60.8 & 1,140 & 188.3 & 162.3 & 1.5 \\
\hline & Toreiyu Tsubasa & 148.6 & 4,940 & 333.8 & 287.7 & 2.6 \\
\hline & Genbi Shinkansen & 134.7 & 5,580 & 415.9 & 358.6 & 3.2 \\
\hline & Furano Biel Noro. & 55.3 & 1,590 & 288.7 & 248.9 & 2.2 \\
\hline \multirow{4}{*}{ Swiss (CHF) } & GoldenPass Line & 191 & 88 & 542.7 & 308.6 & 2.8 \\
\hline & Bernina Express & 156 & 63.6 & 480.3 & 273.0 & 2.5 \\
\hline & Glacier Express & 290 & 152.2 & 618.2 & 351.5 & 3.2 \\
\hline & Cheese Train & 33 & 8 & 285.6 & 162.4 & 1.5 \\
\hline Australia (\$) & Kuranda Scenic & 34 & 50 & $1,310.3$ & $1,001.2$ & 9.0 \\
\hline \multirow{4}{*}{ England (£) } & Ftestiniog Railway & 21.6 & 16.1 & $1,092.7$ & 916.8 & 8.3 \\
\hline & Welsh Highland. & 40 & 26.7 & 978.6 & 821.1 & 7.4 \\
\hline & Cumbrian Mount. & 528 & 99 & 274.9 & 230.6 & 2.1 \\
\hline & The Waverley & 613 & 115 & 275.0 & 230.8 & 2.1 \\
\hline Austria $(€)$ & Schafbergbahn Cog. & 5.85 & 17 & $3,766.2$ & $2,688.7$ & 24.3 \\
\hline
\end{tabular}




\section{LITERATURE SYNTHESIS}

It is necessary to explore how much the individuals are willing to pay for the provision of certain services, and even of public transportation goods as well. Moreover, estimating the economic value for a change in specific train services provides basic information as far as the new fare issues of the sightseeing trains are concerned. Assessing each service value of sightseeing trains, however, is a difficult exercise and requires non-market techniques such as Contingent Valuation Method (CVM). CVM can be used to estimate both the use and non-use economic values, and it is the most widely used method for estimating non-use values.

CVM is a survey-based approach, in which representative respondents are asked to report information about their maximum Willingness to Pay (WTP) to secure or to avoid the supposed change in the level of provision of a certain service. There are two types of questionnaire surveys depending on the type of question: one is an open-question method such as a direct question method and a payment card format; another is a closed-question method such as dichotomous choice method (or a bidding game).

In the context of dichotomous choice methods, Lee et al. [3] is the only relevant study as far as the author knows; they tried to estimate the economic evaluation of sightseeing trains using CVM. They reported that people (who have ridden in the past at least) are willing to pay additional $28.4 \%$ for the O-train and $54.9 \%$ for the V-train, compared to the current fare. However, this study investigated only two types of sightseeing trains, and questioned only the overall intention to pay for it without specifying a certain type of services. Further, the response was limited to the values presented in the questionnaires by fixing the specific fee throughout the survey, which means there were no flexibilities in choosing anything other than the suggested values. Likewise, Willis [4] used the dichotomous choice CVM, in the context of ecosystem services and environmental goods, to estimate an appropriate admission fee by changing the number and distribution of bid levels. It revealed the number and sequence of bid levels impacting the accuracy in estimating a revenue maximizing price. Sanz et al. [5] used a double-bounded dichotomous choice format to measure the economic value of the National Sculpture Museum.
Unlike dichotomous choice methods, a few studies designed open-ended questions in which respondents can state their maximum WTP. Santagata et al. [6] designed a particular sequence of valuation questions to assess the economic value of the tourism programs: a single bounded discrete choice question and follow-up by an open-ended question to state their maximum WTP. They used a conventional logit model and spike logit model for single bounded discrete choice datasets and a Tobit censored regression model for open-ended bid data sets. Such questioning strategy allowed comparison of WTP values obtained from single bounded discrete choice formats with those obtained from open-ended questions. Lee et al. [7] analysed the factors affecting the efficiency of public libraries by using the Tobit model. Jeong [8] evaluated the monetary value of improving the air quality of Seoul by using multiple regression model and Tobit model. Heo et al. [9] estimated the economic value of regional cultural resources based on the perception of residents. They assumed that the user's demand for tourist goods is grouped at a limited value. Lee et al. [10] also estimated the amount of payment that users perceive about the introduction of the traffic accident emergency notification system. The Tobit model was widely used in estimating the economic values of certain services obtained from open-ended questioning strategy.

In conclusion, both the open-ended and dichotomous choice question formats have advantages and disadvantages. Using open-ended questions is a more direct measure of willingness to pay. However, the open-ended format is more burdensome to respondents as it requires them to offer a response with little or no assistance. Consequently, the open-ended question format potentially increases the likelihood that respondents will not answer the question [11]. In contrast, the dichotomous choice question format provides a potential improvement over the open-ended question format in that the respondent's burden is substantially decreased. However, responses to dichotomous choice questions only provide a bound on individuals' actual willingness to pay, and therefore a relatively large sample size is needed to estimate the willingness to pay [12]. The dichotomous choice questioning strategy is the additional time required to complete the questionnaire and too many questions being created if there are many different types of services to measure the economic values [4]. Also, the 
possible biases are introduced by dichotomous choice questions being repeated until the rejection of a bid amount is obtained [13]. In the study, therefore, the survey has been designed as a formant of open-ended question.

In summary, the aim of the paper is three-fold: to better understand the individual's willingness to pay for the optimal provision of train services to be provided, to propose a new fare that maximizes the revenue to help those who in charge of fare adjustment make a reasonable decision, and lastly to offer a reliable empirical contribution to the contingent valuation literature in the area of sightseeing train services using four different statistical structures. Such research has largely remained unexplored in the railway transportation literature, and further there are no contributions in the sightseeing train industry.

\section{DATA DESCRIPTION}

The CVM has been applied through conducting the survey in which individuals are directly asked how much they would be willing to pay for a (change in) specific service. The individuals are asked to state their willingness to pay, contingent on a scenario described to the respondent. Each respondent is asked whether they accept the proposed amount. This method is easy and simple as the answer is marked 'Yes', 'No', but the number of questions is too large when there are two or more services to estimate the economic value. In this research, there are seven types of services, meaning that the number of questionnaires becomes too large when using the conventional method (i.e. stated preferences). Therefore, we did not offer a predetermined amount of increment in the survey as the format of dichotomous choice questions. Instead, we adopted a format of open-ended questions so that they are asked directly to write the percentage they would be willing to pay more, based on their own fare. If there is no willingness to increase, they are guided to answer ' 0 '.

The survey was conducted online and in the field in August 2017. There were 1,997 e-mails sent to those who had experienced at least one of the sightseeing trains, of whom 1,100 responded, 700 (7.8\%) remained valid.

The questionnaire consists of mainly three subjects as follows:
Table 3 - Summary statistics for explanatory variables

\begin{tabular}{|c|c|c|}
\hline \multicolumn{2}{|c|}{ Variables } & Proportion of \\
\hline \multirow{6}{*}{ Sightseeing trains } & O-train & 0.22 \\
\hline & V-train & 0.10 \\
\hline & S-train & 0.45 \\
\hline & G-train & 0.10 \\
\hline & A-train & 0.07 \\
\hline & D-train & 0.06 \\
\hline \multirow{5}{*}{$\begin{array}{l}\text { Paid train fares } \\
(10,000 \text { won }=\$ 8.3 \\
\text { in USD) }\end{array}$} & $0 \sim 10,000$ won & 0.09 \\
\hline & $\sim 15,000$ won & 0.26 \\
\hline & $\sim 20,000$ won & 0.22 \\
\hline & $\sim 25,000$ won & 0.19 \\
\hline & $+25,000$ won & 0.24 \\
\hline \multirow{3}{*}{$\begin{array}{l}\text { Freq. of annual } \\
\text { boarding }\end{array}$} & $0 \sim 1$ & 0.55 \\
\hline & $2 \sim 3$ & 0.35 \\
\hline & $4+$ & 0.10 \\
\hline \multirow{3}{*}{ Boarding purpose } & $\begin{array}{c}\text { Travelling } \\
\text { (enjoying the train } \\
\text { itself) }\end{array}$ & 0.42 \\
\hline & $\begin{array}{c}\text { Moving } \\
\text { (moving to certain } \\
\text { destinations) }\end{array}$ & 0.41 \\
\hline & For both & 0.17 \\
\hline \multirow{5}{*}{$\begin{array}{l}\text { Accompanying } \\
\text { type }\end{array}$} & Alone & 0.18 \\
\hline & Family & 0.50 \\
\hline & Couple & 0.10 \\
\hline & Friends & 0.20 \\
\hline & Other & 0.02 \\
\hline \multirow{2}{*}{ Gender } & Female & 0.50 \\
\hline & Male & 0.50 \\
\hline \multirow{2}{*}{ Marital status } & Married & 0.62 \\
\hline & Single & 0.38 \\
\hline \multirow{6}{*}{ Age } & $\leq 20$ & 0.05 \\
\hline & $21 \sim 30$ & 0.19 \\
\hline & $31 \sim 40$ & 0.29 \\
\hline & $41 \sim 50$ & 0.25 \\
\hline & $51 \sim 60$ & 0.15 \\
\hline & $>60$ & 0.07 \\
\hline \multirow{2}{*}{$\begin{array}{l}\text { Presence of fixed } \\
\text { income }\end{array}$} & Yes & 0.81 \\
\hline & No & 0.19 \\
\hline \multirow{4}{*}{$\begin{array}{l}\text { Monthly household } \\
\text { income }\end{array}$} & $\leq 2$ million won & 0.07 \\
\hline & $\leq 4$ million won & 0.35 \\
\hline & $\leq 6$ million won & 0.31 \\
\hline & $>6$ million won & 0.27 \\
\hline \multicolumn{2}{|c|}{ Number of observations } & 1,013 \\
\hline
\end{tabular}


Lim K-K. Estimating a New Fare for Sightseeing Trains Based on Willingness to Pay

Table 4-Descriptive statistics of willingness to increase the current fare

\begin{tabular}{|c|c|c|c|c|c|c|c|}
\hline \multirow{2}{*}{ Service types } & \multicolumn{3}{|c|}{$\begin{array}{l}\text { Willingness to increase at } \\
\text { minimum [\%] }\end{array}$} & \multicolumn{3}{|c|}{$\begin{array}{l}\text { Willingness to increase at maxi- } \\
\text { mum }[\%]\end{array}$} & \multirow{2}{*}{$\begin{array}{c}\text { Diff. between } \\
\text { avgs. } \\
{[\%]}\end{array}$} \\
\hline & Avg. & $\begin{array}{l}\text { Cum. freq. } \\
\text { (at } 95 \% \text { ) }\end{array}$ & Max. & Avg. & $\begin{array}{l}\text { Cum. freq. } \\
\text { (at } 95 \% \text { ) }\end{array}$ & Min. & \\
\hline Performance and recreation & 10.2 & 40.0 & 125.0 & 20.1 & 60.0 & 150.0 & 9.9 \\
\hline Slow-moving operation & 9.2 & 30.0 & 80.0 & 17.5 & 50.0 & 100.0 & 8.3 \\
\hline $\begin{array}{l}\text { Seating type } \\
\text { (standard vs. observable seat) }\end{array}$ & 10.2 & 40.0 & 120.0 & 19.2 & 60.0 & 140.0 & 9.0 \\
\hline $\begin{array}{l}\text { Seating type } \\
\text { (room vs. observable seat) }\end{array}$ & 12.4 & 50.0 & 120.0 & 23.3 & 70.0 & 130.0 & 10.9 \\
\hline Tourist commentary & 8.1 & 30.0 & 110.0 & 16.0 & 50.0 & 120.0 & 7.9 \\
\hline Locally connected tour service & 7.4 & 30.0 & 110.0 & 14.3 & 50.0 & 120.0 & 6.9 \\
\hline Overall services & 10.0 & 30.0 & 110.0 & 18.6 & 50.0 & 130.0 & 8.6 \\
\hline
\end{tabular}

Use of trains: fare, annual usage, boarding purpose (moving to the destination only, travelling itself, etc.), accompanying type (alone, family, couple, etc.);

Individual characteristics: gender, marital status, age, occupation status and household income;

Percentage increment (a minimum-maximum interval) they would be willing to raise by different type of train services: various activities such as performances and shows, slow-moving operation, seating type (observable and room typed), tourist commentary, locally connected tour services, and overall service including above.

The field surveys were conducted on sightseeing trains and surveyed 313 passengers. A total of 1,013 were used for analysis, including 700 valid online samples.

The statistical description of samples has been presented in Table 3. There are 505 males and 508 females, and 164 respondents $(16.2 \%)$ belong to the age group of 36 40 and $130(12.8 \%)$ to the age of $26 \sim 35$. There are $629(62.1 \%)$ married. There were 817 respondents $(80.7 \%)$ who answered that they have a monthly income. In terms of household monthly income in average, $21.5 \%$ have below 3 million won and $18.9 \%$ more than 7 million won. There were $42.3 \%$ respondents who replied that they used trains purely for travel purposes. A half of respondents accompanied their family members.

Table 4 shows the range of percentages by which the people would be willing to increase their current fare by service types provided in sightseeing trains. Regardless of the service types, most respondents answered that they are willing to pay an additional $10.0 \%$ to $18.6 \%$. People are more likely to increase their current fare when upgrading their observable seat to a room typed, which is the highest value in the minimum and maximum willingness.

\section{MODEL DESCRIPTION}

Tobit model, also called a censored regression model, is designed to estimate linear relationships between variables when there is either left- or right-censoring in the dependent variable (also known as censoring from below and above, respectively). Tobit-censored regression model is useful when a dependent variable is a quantitative variable but cannot be observed within a certain range and has a limited value. Tobit analysis method, a member of the censored regression model, has been applied to the estimation of willingness to raise fares. This method is also useful when a large number of dependent variables is observed as zero.

$$
\begin{aligned}
& y_{i}^{*}=\beta x_{i}+\varepsilon_{i} \quad \varepsilon_{i} \sim N\left(0, \sigma^{2}\right) \\
& y_{i}=y_{i}^{*} \text { if } y_{i}^{*}>0 \\
& y_{i}=0 \text { if } y_{i}^{*}<0
\end{aligned}
$$

where: $y_{i}$ is the amount of observed payment; $y_{i}{ }^{*}$ is the amount of potential payment (willingness to increase at minimum and maximum); $\beta$ s are coefficients to be estimated; $x_{i}$ is the vector of explanatory variable (i.e. gender, marital status, age, household income level, experience of sightseeing trains, fares, main purpose of boarding); error term $\varepsilon_{i}$ is analysed with four different probability distributions: normal, logistic, log-normal distribution and Weibull distribution. The Weibull distribution is in general known better fitted to the estimation of economic values of non-market goods.

The following likelihood function has been applied for the estimation. 


$$
\ln L=\sum \ln \left(1-\Phi\left(\frac{\beta x_{i}}{\sigma_{u}}\right)\right)+\sum\left[\ln \sigma_{u}+\ln \Phi\left(\frac{y_{i}-\beta x_{i}}{\left.\sigma_{u}\right)}\right)\right]
$$

Coefficient $\beta$ is estimated by maximizing the $\ln L$. The first term is the sum of $y_{i}=0$ and the second term is the sum of $y_{i}>0$, and $\Phi(\cdot)$ denotes a normal cumulative distribution function.

If the new fare increment is within the range of the respondent's answer, then the respondent will still use a sightseeing train. Assuming the range of respondent's answers follows a normal distribution, the average WTP is calculated by the following equation.

$$
\begin{aligned}
& W T P=\Phi\left(\frac{\beta x_{i}^{\prime}}{\sigma}\right)\left(\beta x_{i}^{\prime}+\sigma \lambda_{i}\right) \\
& \lambda_{i}=\frac{\phi\left(\beta x_{i}^{\prime} / \sigma\right)}{\Phi\left(\beta x_{i}^{\prime} / \sigma\right)}
\end{aligned}
$$

where: $\phi(\cdot)$ notes a normal probability density function. The other WTPs on different probability distributions are measured as follows.

Logistic distribution:

$W T P=\sigma \ln \left(1+e^{\beta x_{i}^{\prime} / \sigma}\right)$

Log-normal distribution:

$W T P=e^{\beta x_{i}^{\prime}+\frac{1}{2} \sigma^{2}}$

Weibull distribution:

$W T P=e^{\beta x_{i}^{\prime}} \Gamma(1+\sigma)$

\section{EMPIRICAL RESULTS}

This section of the paper presents the models estimated for willingness to increase the current fares from the 1,013 samples. The estimation was performed by seven different types of train service: recreational activities, slow-moving operation, seating type (standard vs. observable and room vs. observable), tourist commentary, locally connected tour and service including all of these. A statistical package SAS Version 9.4 was used for the estimations. The analysis was performed based on the four statistical distributions: standard normal, logistic, Weibull and log-normal distribution.

Due to the limitation of the paper, only the outputs in terms of 'seat type (standard vs. observable)' and 'overall train service' have been presented. They are the outputs of standard normal distribution which has the smallest mean absolute error in predictive validation.

Recognition of willingness to fare increases can be interpreted by looking at the coefficient sign $(+$ or -$)$ of each variable. In all models, a positive coefficient indicates that the corresponding factor is associated with a greater agreement on the issue of fare increases. In general, the directionality of the impacts was estimated to be similar across all four statistical structures. For the category variables, a 'reference' was defined throughout the estimations since the variables do not represent a magnitude as ages and incomes, instead, they are converted into binary variables. For example, the D-train had been defined as a reference among six types of sightseeing trains, the sign of coefficients can be interpreted as the relative directionality to the D-train.

\subsection{Model outputs}

Table 5 presents the model outputs of the willingness to increase at both the minimum and the maximum for the economic value of the seat type (comparison of a standard seat and an observable seat). On the type of sightseeing trains, the coefficients turned out all negatives in V, S and G-trains, which means the passengers are less likely to increase the current fare, compared to the D-train. These effects were intuitively reasonable since the D-train is mostly for the purpose of travelling the $\mathrm{DMZ}$ and also the only means of transportation to travel there. For the boarding purposes, the directionality of the impact on 'travelling' was estimated to be similar, which means the greater purpose of travelling the more likely to pay. Likewise, the willingness increases with an increasing frequency of annual boarding.

In contrast, the willingness decreases with aging. In the case of accompanying type during travel, passengers accompanying others (except for family, couples and friends) are less likely to increase their fare. Those with fixed incomes are more likely to agree than others. Such explanations are almost identical in both models except for the variable 'Presence of fixed income' (although it is statistically insignificant, the negative sign means less income, the less likely to increase their own fare). There are no statistically significant evidences in the intention by train fare, gender, marital status, and monthly household incomes, but their directionality of the factors is intuitively reasonable.

Table 6 presents the model outputs of the willingness to increase at both minimum and maximum for the economic value of overall sightseeing train services. On types of sightseeing train, the coefficients turned out negative in V, S, and G-trains as well, which means customers are less likely to increase their 
Lim K-K. Estimating a New Fare for Sightseeing Trains Based on Willingness to Pay

current fare (again the D-train has been used as a reference variable). An identical tendency was observed in the age. The willingness of increase was relatively lower in older generations than in the younger ones. Also, those whose boarding purpose is 'Travelling' are more likely to increase their current fare. It seems quite clear that those boarding the train for the travelling purpose are more likely to enjoy their journey than those who simply use the train as a means of transportation. No statistically significant evidence

Table 5 - Model outputs of willingness to increase the current fare according to seat types

\begin{tabular}{|c|c|c|c|c|}
\hline \multirow{2}{*}{ Variables } & \multicolumn{2}{|c|}{$\begin{array}{l}\text { Willingness to increase } \\
\text { at minimum }\end{array}$} & \multicolumn{2}{|c|}{$\begin{array}{l}\text { Willingness to increase } \\
\text { at maximum }\end{array}$} \\
\hline & Coeff. & p-value & Coeff. & p-value \\
\hline Constant & 15.85 & $<.001 * *$ & 24.14 & $<.001 * *$ \\
\hline \multicolumn{5}{|l|}{ Type of sightseeing train } \\
\hline O-train & -2.98 & 0.234 & -4.20 & 0.203 \\
\hline V-train & -7.51 & $0.008 * *$ & -8.97 & $0.016^{* *}$ \\
\hline S-train & -8.17 & $0.001 * *$ & -9.04 & $0.005 * *$ \\
\hline G-train & -6.69 & $0.021 * *$ & -8.74 & $0.022 * *$ \\
\hline A-train & -0.67 & 0.827 & 0.31 & 0.939 \\
\hline D-train & reference & & reference & \\
\hline Train fare & -0.15 & 0.740 & -0.60 & 0.309 \\
\hline Freq. of annual boarding & 0.94 & $0.100^{*}$ & 1.29 & $0.086^{*}$ \\
\hline \multicolumn{5}{|l|}{ Boarding purpose } \\
\hline Travelling & 5.84 & $<.001 * *$ & 7.52 & $<.001 * *$ \\
\hline Moving & reference & & reference & \\
\hline Both & -2.72 & 0.109 & -1.97 & 0.361 \\
\hline \multicolumn{5}{|l|}{ Accompanying type } \\
\hline Alone & reference & & reference & \\
\hline Family & 1.16 & 0.486 & 1.18 & 0.582 \\
\hline Couple & 1.07 & 0.636 & 2.13 & 0.466 \\
\hline Friends & -1.39 & 0.469 & -0.70 & 0.778 \\
\hline Others & -9.31 & $0.055^{*}$ & -12.93 & $0.035^{* *}$ \\
\hline \multicolumn{5}{|l|}{ Gender } \\
\hline Female & -1.64 & 0.169 & -1.34 & 0.386 \\
\hline Male & reference & & reference & \\
\hline \multicolumn{5}{|l|}{ Marital status } \\
\hline Married & -2.37 & 0.132 & -1.71 & 0.403 \\
\hline Single & reference & & reference & \\
\hline Age & -0.95 & $0.003 * *$ & -0.66 & $0.100 *$ \\
\hline \multicolumn{5}{|l|}{ Presence of fixed income } \\
\hline No & -3.77 & $0.015 * *$ & -2.99 & 0.131 \\
\hline Yes & reference & & reference & \\
\hline Monthly household income & 0.11 & 0.634 & 0.20 & 0.513 \\
\hline Scale parameter & 16.99 & - & 22.59 & - \\
\hline
\end{tabular}

** means statistically significant at $\alpha=0.05$ and $*$ at $\alpha=0.1$. 
Lim K-K. Estimating a New Fare for Sightseeing Trains Based on Willingness to Pay

Table 6-Model outputs of willingness to increase the current fare according to overall service

\begin{tabular}{|c|c|c|c|c|}
\hline \multirow{2}{*}{ Variables } & \multicolumn{2}{|c|}{$\begin{array}{l}\text { Willingness to increase } \\
\text { at minimum }\end{array}$} & \multicolumn{2}{|c|}{$\begin{array}{l}\text { Willingness to increase } \\
\text { at maximum }\end{array}$} \\
\hline & Coeff. & p-value & Coeff. & p-value \\
\hline Constant & 14.62 & 0.000 & 23.09 & $<.001$ \\
\hline \multicolumn{5}{|l|}{ Type of sightseeing train } \\
\hline O-train & -4.64 & $0.065^{*}$ & -6.28 & $0.038 * *$ \\
\hline V-train & -7.39 & $0.009 * *$ & -10.61 & $0.002 * *$ \\
\hline S-train & -8.75 & $0.000 * *$ & -8.95 & $0.002 * *$ \\
\hline G-train & -7.10 & $0.015 * *$ & -7.98 & $0.022 * *$ \\
\hline A-train & -1.32 & 0.666 & -2.15 & 0.560 \\
\hline D-train & reference & & reference & \\
\hline Train fare & -0.15 & 0.740 & -0.60 & 0.309 \\
\hline Freq. of annual boarding & 0.94 & $0.100^{*}$ & 1.29 & $0.086^{*}$ \\
\hline \multicolumn{5}{|l|}{ Boarding purpose } \\
\hline Travelling & 5.74 & $<.001 * *$ & 6.29 & $<.001 * *$ \\
\hline Moving & reference & & reference & \\
\hline Both & -0.80 & 0.635 & 0.44 & 0.821 \\
\hline \multicolumn{5}{|l|}{ Accompanying type } \\
\hline Alone & reference & & reference & \\
\hline Family & 2.19 & 0.189 & 3.37 & $0.088^{*}$ \\
\hline Couple & 0.05 & 0.981 & -0.40 & 0.881 \\
\hline Friends & -1.91 & 0.323 & -0.26 & 0.907 \\
\hline Others & -1.71 & 0.712 & -4.23 & 0.439 \\
\hline \multicolumn{5}{|l|}{ Gender } \\
\hline Female & -1.71 & 0.151 & -0.94 & 0.509 \\
\hline Male & reference & & reference & \\
\hline \multicolumn{5}{|l|}{ Marital status } \\
\hline Married & -0.74 & 0.636 & -0.24 & 0.897 \\
\hline Single & reference & & reference & \\
\hline Age & -1.04 & $0.001 * *$ & -0.89 & $0.017 * *$ \\
\hline \multicolumn{5}{|l|}{ Presence of fixed income } \\
\hline No & -1.73 & 0.265 & -1.35 & 0.455 \\
\hline Yes & reference & & reference & \\
\hline Monthly household income & -0.11 & 0.635 & -0.03 & 0.925 \\
\hline Scale parameter & 16.99 & - & 20.72 & - \\
\hline
\end{tabular}

* means statistically significant at $\alpha=0.05$ and $*$ at $\alpha=0.1$.

was found in the intention by train fare, frequency of annual boarding, gender, marital status, presence of fixed income and monthly household incomes, but their directionality of the factors is intuitively reasonable except for household incomes.

\subsection{Predictive validations}

The estimated models by service types provided in the sightseeing trains were applied to the samples, and the predicted WTPs are compared with the observed values. The results from applying the 
Tobit model with four statistical distributions are discussed here (standard normal, logistic, Weibull, and log-normal distributions).

The extent of the difference between the observed and predicted WTP for each of the four statistical distributions is quantified by using the Mean Absolute Error (MAE) measure. The MAE is then the average of this error over all respondents. The MAE values are reported for each train service type and for each statistical distribution in Table 7. On examining the MAEs it is found that the normal distribution has the lowest values for all train service types and the log-normal distribution has the highest errors. At the same time, the Weibull distribution also has a greater variance of absolute errors (especially for locally connected tour service). Thus, larger errors are possible for WTPs by service types when predictions are made by using the log-normal and Weibull distributions.

Overall, the WTPs by train service types of the normal distributions in Table 7 are explained below. The average difference between the maximum and minimum WTP for the overall train service is $8.7 \%$.
In detail, the ranges of minimum and maximum WTPs for each service type provided in the sightseeing trains are as follows, in order: $10.9 \%$ for room typed seating compared to observable seating, $10.0 \%$ for recreational activity services, $9.2 \%$ for observable seating compared to standard, $8.3 \%$ for the slow-moving operation, $8.0 \%$ for the tourist commentary service and $7.1 \%$ for the locally connected tour service. On the magnitudes of maximum and minimum WTPs each, the greater the interval between the minimum and maximum, both WTPs for each service type are high. This means that the individuals who have maximum WTP for the service are more likely to pay for them equally high at the minimum increase of the service charge.

It is suggested that the economic value of services that have high willingness to raise should be first reflected on the fare so that passengers are less likely to be sensitive to such an increment rather than the other service types. The output of predictive validation from the normal distribution is applied for determining an appropriate fare adjustment strategy in the next section.

Table 7 - Estimation of WTPs by statistical distributions

\begin{tabular}{|c|c|c|c|c|c|c|c|c|c|c|c|}
\hline \multirow{2}{*}{\multicolumn{3}{|c|}{ Service types provided }} & \multicolumn{3}{|c|}{ Normal dist. } & \multicolumn{2}{|c|}{ Logistic dist. } & \multicolumn{2}{|c|}{ Weibull dist. } & \multicolumn{2}{|c|}{ Log-normal dist. } \\
\hline & & & \multirow{2}{*}{$\begin{array}{r}\text { WTP } \\
11.0\end{array}$} & \multirow{3}{*}{$\begin{array}{c}\text { (Max- } \\
\text { Min) }\end{array}$} & \multirow{2}{*}{$\begin{array}{c}\text { MAE } \\
7.7\end{array}$} & \multirow{2}{*}{$\begin{array}{l}\text { WTP } \\
9.4\end{array}$} & \multirow{2}{*}{$\begin{array}{r}\text { MAE } \\
-8.0\end{array}$} & \multirow{2}{*}{$\begin{array}{l}\text { WTP } \\
14.5\end{array}$} & \multirow{2}{*}{$\begin{array}{l}\text { MAE } \\
42.0\end{array}$} & \multirow{2}{*}{$\begin{array}{l}\text { WTP } \\
14.5\end{array}$} & \multirow{2}{*}{$\begin{array}{l}\text { MAE } \\
42.0\end{array}$} \\
\hline \multirow{2}{*}{\multicolumn{2}{|c|}{ Recreational activities }} & Min & & & & & & & & & \\
\hline & & Max & 21.0 & & 4.2 & 19.1 & -5.2 & 25.7 & 27.5 & 25.9 & 28.8 \\
\hline \multirow{2}{*}{\multicolumn{2}{|c|}{ Slow-moving operation }} & Min & 9.8 & \multirow{2}{*}{ (8.3) } & 6.4 & 8.5 & -6.9 & 13.8 & 50.4 & 14.0 & 52.1 \\
\hline & & Max & 18.1 & & 3.8 & 16.5 & -5.3 & 22.7 & 30.3 & 22.9 & 31.1 \\
\hline \multirow{4}{*}{$\begin{array}{l}\text { Seating } \\
\text { type }\end{array}$} & Standard & Min & 11.0 & \multirow{2}{*}{$(9.2)$} & 7.9 & 9.4 & -8.0 & 13.9 & 36.6 & 14.2 & 39.8 \\
\hline & Observable & Max & 20.2 & & 4.9 & 18.2 & -5.3 & 22.9 & 19.3 & 23.4 & 21.7 \\
\hline & \multirow{2}{*}{$\begin{array}{l}\text { Room } \\
\text { vs. } \\
\text { Observable }\end{array}$} & Min & 13.3 & \multirow{2}{*}{$(10.9)$} & 7.4 & 11.5 & -7.3 & 16.1 & 30.4 & 16.5 & 33.3 \\
\hline & & Max & 24.2 & & 4.2 & 22.0 & -5.4 & 27.1 & 16.4 & 27.7 & 19.0 \\
\hline \multirow{2}{*}{\multicolumn{2}{|c|}{ Tourist commentary }} & Min & 8.9 & \multirow{2}{*}{$(8.0)$} & 10.8 & 7.4 & -8.5 & 12.3 & 52.3 & 12.0 & 49.3 \\
\hline & & Max & 16.9 & & 6.1 & 15.0 & -6.0 & 20.7 & 29.6 & 20.7 & 29.4 \\
\hline \multirow{2}{*}{\multicolumn{2}{|c|}{$\begin{array}{l}\text { Locally connected tour } \\
\text { service }\end{array}$}} & Min & 8.1 & \multirow{2}{*}{$(7.1)$} & 8.4 & 7.0 & -5.7 & 12.5 & 67.8 & 12.6 & 69.4 \\
\hline & & Max & 15.2 & & 6.1 & 13.4 & -6.4 & 20.0 & 39.1 & 20.0 & 39.6 \\
\hline \multirow{2}{*}{\multicolumn{2}{|c|}{ Overall train service }} & Min & 10.7 & \multirow{2}{*}{$(8.7)$} & 7.8 & 9.2 & -7.9 & 13.9 & 39.6 & 14.0 & 40.5 \\
\hline & & Max & 19.4 & & 4.2 & 17.5 & -6.2 & 22.0 & 18.3 & 22.5 & 20.7 \\
\hline \multicolumn{3}{|c|}{ Avg. MAE } & - & & 6.4 & - & -6.6 & - & 35.7 & - & 36.9 \\
\hline
\end{tabular}




\section{PROPOSING A NEW FARE}

As mentioned in Figure 2, the average transport cost of the entire sightseeing trains is 210.47 won $/$ seat $\cdot \mathrm{km}$ based on the expenditure data of sightseeing trains in 2017. The cost is composed of two types of expenditures: one is for transport (199.69 won $/ \mathrm{seat} \cdot \mathrm{km})$ and another for service (10.77 won $/$ seat $\cdot \mathrm{km}$ ). Further, the average expenditure for train operation is almost twice compared to the current unit fare $110.81 \mathrm{won} / \mathrm{seat} \cdot \mathrm{km}$. No matter how the cost has to be compensated to a certain amount of expenditure, it is practically difficult to raise the current fare almost double. Further, this could rather result in less operating profits due to a decrease of passengers. As the WTPs range from $8.1 \%$ to $13.3 \%$ at minimum and $15.2 \%$ to $24.2 \%$ at maximum, a possible increase rate of current fares is supposed to be at least $8.1 \%$ to a maximum $24.2 \%$, which means the double price hike that makes income and expenditure equal is almost impossible in practice. In the study, the WTP estimated for the overall service is used as the range of price hike since such WTP is almost identical as the average WTPs of six different types of train service as presented in Table 7.

Next, it is necessary to analyse the demand elasticity to price hike. There is a law of demand that consumers increase their purchases when prices fall, and vice versa, which applies equally to railway transport services. To calculate the demand elasticity of price, it is expressed as a ratio of the price and the demand rate and it is generally expressed as a negative value. On the basis of one in absolute, the demand elasticity is defined as greater than one if the demand rate of reduction is greater than the rate of increase of the commodity price. In this case, when the buyer's response is sensitive compared to price changes, the profits will be reduced when the price increases. Conversely, if the demand reduction rate is smaller than that of a commodity price increase, then demand elasticity becomes less than one and this is referred to as price inelastic.

The direct estimation of demand elasticity to train fares is most desirable by observing changes in the number of passengers before and after the fare change. However, there have been no fare variations since the opening year in 2013. Even though there is an Alternative to estimate the variations in demand using annual inflation rates, no statistical relationship between the demand and the inflation has been observed for the last four years. In the study, therefore, proposing a new fare that guarantees maximum profits is based on the results of the previous research on the demand elasticity to price.

Korail [14] conducted a survey of whether people would use sightseeing trains if the current fare goes up for O, V, S, D, G and A-train, and reported a demand elasticity of -2.33 (which means a reduction in travel demand of $23.3 \%$ when fares are increased by $10.0 \%$ ). However, this value is $18.9 \%$ higher than the demand elasticity of taxis $(-1.96)$ studied by Hwang et al. [15]. In addition, they reported demand elasticities to price for motor vehicles $(-0.51)$, buses $(-0.11)$, and subways $(-0.11)$, which are less sensitive than those presented by Korail [14]. Moon [16] also presented the elasticity of transport demand for freight trains as -0.35 using a time series analysis. It implies that the demand elasticity of the sightseeing trains will be at least higher than that of the freight trains. In addition, Lee et al. [17] proposed the demand elasticity of KTX (Korea Train eXpress, a high-speed train) and Saemaul (a conventional train covering nationwide) as -0.2454 and -0.6806 , respectively.

The fare rate for sightseeing trains is the same as the Saemaul, and both are all in the category of conventional trains. Therefore, the demand elasticity of sightseeing trains would be at least above the Saemaul's (-0.6806) when considering the sightseeing trains are more likely to be used for leisure travel purpose than the Saemaul. As expected, there have been a number of notable former studies in which the demand by leisure travel purpose is found to be more sensitive to price, than the demand by non-leisure travel purpose $[18,19,20]$. In summary, the demand elasticities to price for the sightseeing trains are expected to be ranged from -2.33 to -0.6806 , but still the spread is too large. Interestingly, Wardman [21] reported a frequency distribution of $99 \%$ elasticities less than two by conducting extensive reviews related to price elasticities of travel demand covering 1,633 elasticity studies for the surface modes of car, rail, bus, and underground with journey purpose, mode, ticket type, area, and distance have been recovered. Further, he revealed the elasticities in leisure and off-peak categories are $31 \%$ higher than commuting and peak trips. Although such evidence on fare elasticities was drawn in a range of different circumstances, this is particularly useful where it is not otherwise possible to obtain independent fare elasticity estimates. Therefore, in the study a preferred elasticity value for the 
sightseeing train is assumed to be $31 \%(-0.8916)$ higher than the Saemaul value (-0.6806), which is within that range of Passenger Demand Forecasting Handbook (PDFH) [22]. PDFH fare elasticity values range from -0.5 in the case of commuting within the London Travelcard area to -1.2 in the case of leisure trips from the rest of the country to London $[22,23]$. Among the six service types, special seats currently pay $15 \%$ more than standard seats, so that this study analyses the demand elasticity for the seat service that passengers are already familiar with and are expected to have the lowest resistance to fare increases.

There are two types of seats in the sightseeing train: a standard and a designated seat. The designated seats are arrayed in separate spaces, such as observable areas, family rooms and floor rooms, and they are 20 to $30 \%$ more expensive compared to standard seats. As presented in Table 7, the estimated maximum WTP for an observable seat is $20.2 \%$ and $24.2 \%$ for a room typed relative to a standard seat. We assumed that the upgraded seat fare is $15 \%$ more expensive than the standard seat throughout the price elasticity estimation (the same as the current service payment scheme as presented in Section 2). The proportion of designated seating areas is about $21 \%$ for G-train, $14 \%$ for S-train and $12 \%$ for A-train, with an average of $16 \%$ for all sightseeing trains.

To apply the price elasticity, two Alternatives were defined depending on whether or not such ratios were applied, and a $3.20 \%$ revenue increase is directly generated by implementing Alternative 2 . All alternatives turn out $5.43 \%$ drops in demand, and the revenue maximizing reaches $0.33 \%$ on
Alternative 1 (assumed all seats are standard) and $3.54 \%$ on Alternative 2 ( $16 \%$ are upgraded seats). Figure 3 shows a change in revenue based on the fare increment.

The maximum possible increases of the fares for Alternatives 1 and 2 without the revenue loss are $12.19 \%$ and $25.71 \%$ (a point revenue variation $=0$ ), respectively. Comparing the responses of individuals on the seating type preferences as shown in Table 4 to the thresholds ensuring no loss of revenue according to fare increases, the willingness to increase the train fare may not always guarantee revenue maximizing. Moreover, trying to increase the fare may not be desirable as far as the changes of fare are policy issues for the public transport sector since there is a slight revenue increase evidenced in both alternatives (the maximum revenue increase for Alternative 2 is merely $0.34 \%$ in actual since the other $3.20 \%$ came directly from the implementation of Alternative 2).

The unit fare that gives the train operator maximum profit based on the demand elasticity is 117.56 won/seat $\mathrm{km}$ for a standard seat on Alternative 1 and $135.19 \mathrm{won} / \mathrm{seat} \cdot \mathrm{km}$ for a designated seat on Alternative 2 as shown in Table 8.

\section{CONCLUSION}

A contingent valuation method has been widely used to estimate the economic value for the optimal provision of public goods, but relatively few empirical CVM studies have been undertaken to reveal the degree of individual preferences for a fare change in railway industry. Further, a survey format was designed as a format of dichotomous choice question,

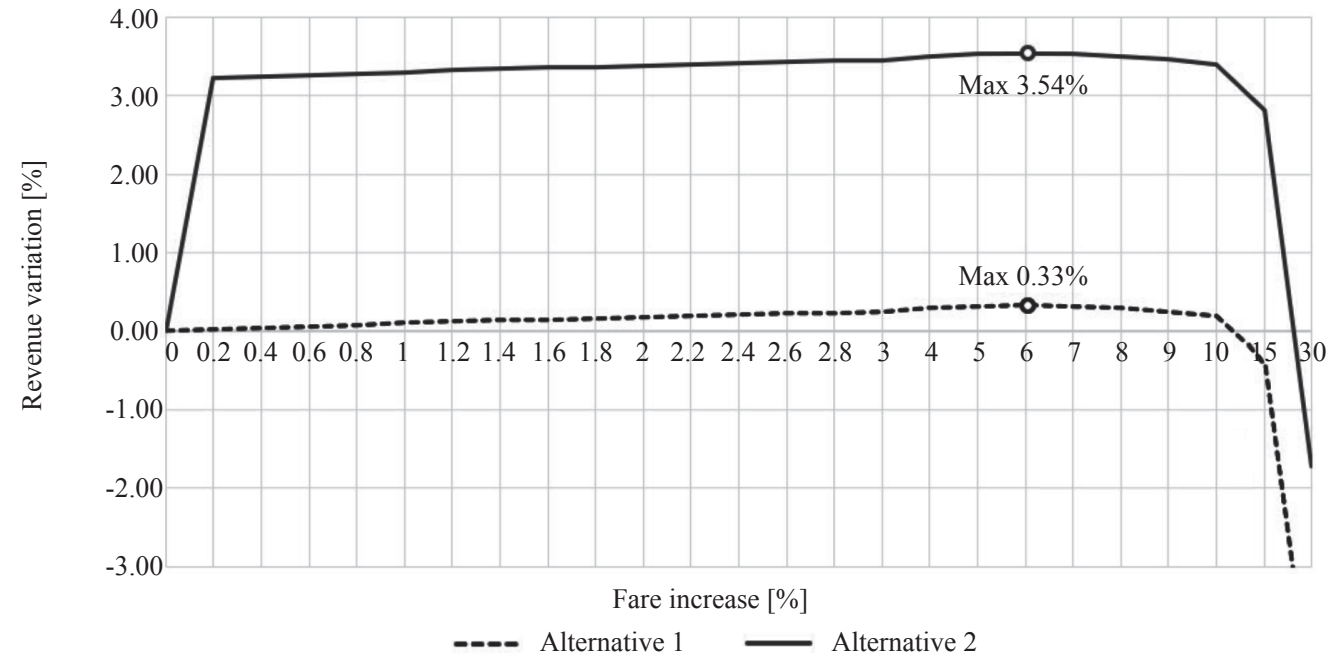

Figure 3 - Profit variation by fare increase 
Lim K-K. Estimating a New Fare for Sightseeing Trains Based on Willingness to Pay

Table 8 - Proposed new fares ensuring maximum revenue by seat types

\begin{tabular}{||c|c|c|c|c|c||}
\hline Seat type & \multirow{2}{*}{$\begin{array}{c}\text { Fare increase ensuring } \\
\text { max. revenue }\end{array}$} & \multirow{2}{*}{$\begin{array}{c}\text { Current base unit } \\
\text { fee }\end{array}$} & \multicolumn{2}{|c|}{ Designated seating } & \multirow{2}{*}{$\begin{array}{c}\text { Total } \\
\text { [won/seat } \cdot \mathrm{km}]\end{array}$} \\
\cline { 4 - 6 } & & & Increased fare at base & Additional & 117.56 \\
\hline \hline \multirow{2}{*}{ Standard } & $6.09 \%$ & 110.81 & 6.75 & - & 135.19 \\
\hline \multirow{2}{*}{ Designated } & & & 6.75 & 17.63 & $(15 \%$ of 117.56$)$ \\
\hline
\end{tabular}

* 15\% is added when choosing an upgrade seat as described in Section 2.

and there are no past studies to determine a revenue maximizing price reflecting the economic value of various types of service in sightseeing trains.

This article has analysed the willingness to pay more for each current service provided in the sightseeing trains with a format of open-ended questions without possible biases and less time consumed throughout the survey [13]. An open-ended valuation of the whole sample was estimated by a Tobit censored regression model with four different statistical distributions. Although the normal distribution as a fundamental approach is well recognized, the empirical comparison of other statistical model applications has not been conducted. In this context, another intent of this study is to undertake a comparative analysis of four different statistical structures for WTP estimates. The structures are compared across seven different types of train service (herein, one is for 'overall service') with meaningfully different WTP responses.

The results indicate that each different type of train service produces various estimates of the WTP reflecting revenue maximizing prices. Predictive validations indicate that the normal distribution models can replicate the WTPs better than Logistic, Weibull, and Log-normal distribution models for all service types. Based on the best performed and applying the demand elasticities to price, two new fares have been proposed: 117.56 won $/ \mathrm{seat} \cdot \mathrm{km}$ (about 6\% increased) for a standard seat, 135.19 won $/ \mathrm{seat} \cdot \mathrm{km}$ ( $22 \%$ increased) for a designated seat.

Those new fares give a very small fraction of revenue maximized depending on how the seats are operated in the train. Although the newly proposed fares guarantee at least revenue maximizing, the results imply that trying to increase the fare may not be desirable as far as the changes of fare can be policy issues for the public transport sector.

The work described in this paper mainly focused on WTP estimations by using four different statistical structures for different types of service provided in sightseeing trains and demonstrated that a much smaller amount of revenue maximization exists. As expected, the revenue maximization highly relies on the magnitude of demand elasticity. Even though that was inferred from the most related and reliable past studies, a little uncertainty still remained in proposing a new accurate fare for sightseeing trains. However, the new fare could be accepted as a reasonable and affordable option to passengers since the option is within the range of predictive WTPs. This study in turn expects that the result can be used as an appropriate guideline in determining a new fare fitted to sightseeing trains.

임광균(Ph.d), 부교수

송원대학교 철도경영학과

ikay@songwon.ac.kr

광주광역시 남구 송암로 $73, \mathrm{~A}-309$

\section{요약}

한국에서 2004년 고속열차가 운영된 이후 일반철도 의 수익은 급격하게 감소되었다. 이러한 상황을 조 금이라도 극복하기 위해 2013 년부터 10 개 경쟁력 있는 노선을 따라 관광열차가 도입되었고, 그 결과 기존 일반열차의 수입대비 비용이 3 배에서 2.5 배로 감소되는 효과를 보였다. 이는 관광열차가 제공하 는 고유 서비스의 가치를 반영하지 않고 기존 일반 열차에 적용되는 운임을 그대로 적용한 성과다. 철 도운송 분야에서 지불의사금액(WTP)에 대한 연구 는 많이 이루어지지 못했다. 특히 관광열차 운임설 정에서 이러한 연구는 전무하다. 이 논문은 개방형 설문 조사 데이터와 4 개의 통계분포를 활용한 Tobit censored regression모형을 사용하여 관광 열차에 대 한 다양한 서비스 유형별로 경제적 가치에 대한 지 불의사금액을 추정하였다. 그 결과 정규분포 모형 이 모든 서비스 유형에서 지불의사금액을 가장 정 확하게 추정하였다. 또한 레크레이션 이벤트, 서행 운행, 좌석유형, 관광해설, 지자체 연계 서비스와 같은 서비스 유형별로 지불의사금액이 서로 다르 다는 것을 분석하였다. 가장 높은 가치로 개별실이 전망석에 비해 $13.3 \sim 24.2 \%$ 더 지불할 의향이 있는 것으로 나타났다. 가격에 대한 수요 탄력성을 적용 할 때, 일반석은 $6 \%$, 지정석은 $22 \%$ 인상할 때 수입 이 최대로 되며, 이때 수입은 $0.33 \sim 3.54 \%$ 까지 증가 되었다. 이 연구는 관광열차에 적합한 새로운 요금 
을 결정하는 데 적절한 가이드라인으로 활용될 것 으로 기대된다.

\section{주요어}

지불의사금액, 관광철도, 수요탄력성, Tobit censored regression모형

\section{ACKNOWLEDGEMENT}

This study was supported by research fund from the Songwon University.

\section{REFERENCES}

[1] KRIC (Korea Railway Industry Information Center). Available from: http://www.kric.go.kr/jsp/industry/rss/ operatingReportList.jsp

[2] Korail. Annual performance of sightseeing train. Korea Railroad Corporation. Report, 2015.

[3] Lee SJ, Kim HK, Ahan SY. Study to Estimate the Economic Value of Railway Services Using a Contingent Valuation Method Focusing on Tourist Train Service in Korea. Journal of the Korean Society for Railway. 2017;20(1): 120-127.

[4] Willis KG. Research Note: Iterative Bid Design in Contingent Valuation and the Estimation of the Revenue Maximizing Price for a Cultural Good. Journal of Cultural Economics. 2002;26(4): 307-324.

[5] Sanz J, Herrero LC, Bedate AM. Contingent Valuation and Semiparametric Methods: A Case Study of the National Museum of Sculpture in Valladolid, Spain. Journal of Cultural Economics. 2003;27(3): 241-257.

[6] Santagata W, Signorello G. Contingent valuation of a cultural public good and policy design: The case of Napoli Musei Aperti. Journal of Cultural Economics. 2000;24(3): 181-204.

[7] Lee SS, Han HN. Analyzing the Influence Factors on Efficiency of Public Libraries in Metropolitan Cities by DEA and Tobit Model. Journal of the Korean Society for Information Management. 2010;41(2): 111-131.

[8] Jeong SY. The Estimation of Domestic Construction Technology Full-Text Services using Tobit Mode. Journal of the Korea Academia-Industrial Cooperation Society. 2016;17(6): 656-662.

[9] Heo CU, Shin DJ. Valuation of Cultural Tourism Resources by the Residents`Willingness to Pay: The Case of Gangneung Danoje Festival. International Journal of Tourism and Hospitality Research. 2010;24(3): 77-90.
[10] Lee YJ, Do MS, Jang TY, Han DS. Comparative Analysis of Calculation Methods on Willingness to Pay for Introduction of Emergency-call System. The Korea Institute of Intelligent Transport Systems. 2015;14(6)-62: 50-59.

[11] Desvousges WH, Smith VK, McGivney MP. A comparison of alternative approaches for estimating recreation and related benefit of water quality improvements. U.S. Environmental Protection Agency. EPA 230-05-83-001, 1983.

[12] Manning R, Lawson S, Newman P, Laven D, Valliere W. Methodological Issues in Measuring Crowding-Related Norms in Outdoor Recreation. Leisure Sciences. 2002;24: 339-348.

[13] Flachaire E, Hollard G. Starting point bias and respondent uncertainty in dichotomous choice contingent valuation surveys. Resource and Energy Economics. 2007;28: 183-194.

[14] Korail. Study on re-establishing railroad tourism performance measurement standard. Korea Railroad Corporation. Report, 2016.

[15] Hwang GY, Lee WC. Estimation of appropriate discount rate for transit fare for public transportation centered on Seoul city. Journal of Korean Society of Transportation. 2000;18(2): 27-37.

[16] Moon JS. Development of support measures for increasing rail freight. The Korea Transport Institute. Report, 2007.

[17] Lee JM, Han SY. A Study on the Fare Elasticities of the Railroad Passenger Demand. Korea Research Institute for Human Settlements. 2012;9: 3-16.

[18] Divisekera S. Economics of Leisure and Non-Leisure Tourist Demand: A Study of Domestic Demand for Australian Tourism. Tourism Economics. 2010;16(1): 117136.

[19] Dwyer L, Forsyth P, Dwyer, W. Tourism Economics and Policy. Edition 2. Channel View Publications; 2020.

[20] Granados N, Gupta A, Kauffman RJ. Online and offline demand and price elasticities: Evidence from the air travel industry. Information Systems Research. 2012;23: 164181.

[21] Wardman M. Price Elasticities of Surface Travel Demand: A Meta-analysis of UK Evidence. Journal of Transport Economics and Policy. 2014;48(3): 367-384.

[22] Worsley T. Rail Demand Forecasting Using the Passenger Demand Forecasting Handbook, On the Moe-Supporting Paper 2. RAC Foundation; December 2012.

[23] Wardman M, Shires JD. Review of fares elasticities in Great Britain. Working Paper. Institute of Transport Studies, University of Leeds, Leeds, UK; 2003. 